\title{
New Central and East-European Cinema
}

\author{
By Christina Stojanova \\ Spring 1998 Issue of KINEMA

\section{UNE NOUVELLE EUROPE: THE DOUBLE QUEST OF NEW CENTRAL AND EAST- EUROPEAN CINEMA}

The Berlin Wall collapsed some eight years ago, along with the repressive totalitarian Communist regimes it came to symbolise, thus neatly wrapping up half a century in the history of Eastern Europe. Little has reached our shores, however, about the effects on everyday life of this unprecedented change, brought about by mostly "velvet" revolutions across the region. In March of this year Cinémathèque Québécoise launched Une Nouvelle Europe: A Panorama of Central and Eastern European Cinema, featuring 28 feature and 5 short films from 8 countries. ${ }^{(1)}$ The selection was also presented in Toronto (Cinematheque Ontario, April 4-May 1, 1997) and in Vancouver (Pacific Cinematheque, March 22-May 1), under the title A New Europe: Reeling After The Fall.

The organisation of the event was an arduous and time consuming task. It took more than a year and a half of persistent work: thorough research and establishing a network of people in Canada and abroad who were ready to help with information, advice and money.

Videos of more than a hundred films, created between 1990 and 1996 were obtained primarily on a friendly basis as the national film institutions in most of these countries have been abolished or function only nominally, with virtually no budget. These contacts were instrumental later in tracking down the prints of the selected films all over the globe. Due to financial constraints, most of them have only one subtitled print, usually in English, and highly in demand.

Dealing with the Western distributors of some of the hottest items was another contentious issue. Their practice to demand unreasonable rental payments (like the North American distributor of Bela Tarr's Satantango, who asked for 1,500 USD per screening), is being swiftly adopted by neophyte Central and Eastern European distributors. Such a policy is certain to further obstruct the access to films from this part of the world, given the financial difficulties, experienced by cultural institutions in this country.

The Panorama, however, would have never happened if it were not for the exclusive and enthusiastic support of people who are preciously rare these days, and one wonders whether such a genuine interest towards national cinemas could ever be instilled in younger people, given the growing indifference towards small -- and poorer -- countries. This is not only a problem of North American education and its traditionally limited concern with overseas lands and cultures. The basic problem lies with the prevailing condescending attitudes towards the New Democracies in Central and Eastern Europe propounded by the media. The blackand-white sensational image carried by the press and television is one of countries ridden with economic and political problems, with corruption and ethnic strife. On this backdrop their cultural products seem somehow second rate and unworthy of particular attention. Especially if they do not corroborate the stereotypes.

With the end of the Cold War, almost overnight, films from Eastern Europe have lost their special aura of dissidence and found themselves struggling on a par with other foreign-language productions for the meagre attention of Western distributors. The global standards of film as entertainment, set by Hollywood, have not been very helpful either. Pace, special effects and glamour seem to relegate artistic quality, psychological depths and moral contemplations -- the stuff Central and Eastern European films are traditionally concerned with -- to the museum of film history. That is why the very idea to organise such a Panorama was a very brave one, indeed, in a sense that similar enterprises are rarely expected to leave the ethnic framework and reach mainstream audiences.

Eastern European cinema was the first industry to suffer a tremendous economic blow immediately after the fall of Communism. The powers-to be reached an amazingly swift consensus with most of the filmmakers that the state-subsidised centralised structure of Eastern European cinema should be dismantled and reorganised into many small, entrepreneurial, market-oriented film companies. The result is more than distressing: thus the national production of fiction films in Bulgaria fell from 21 in 1989 to 4 in 1994, in Hungary from 21 
to 6 in 1993, in Slovakia from 10 to 3 in 1993, in the Czech Republic from 22 to 6 in 1993, etc. While the film production in Poland and Romania, and last year in the Czech Republic, has returned to its pre-1989 figures $^{(2)}$ thanks to the financial support, provided by the national television, the theatrical network in these countries shares the same sorrowful fate as in the others: in Poland the number of cinema theatres has fallen from 1792 for 1989 to below 500 in 1994; in Romania from 612 to 300; in the Czech Republic from 1326 to 850; in Slovakia from 774 to 300; and in Bulgaria from 3069 to 148 and in Hungary from 3069 to 114. ${ }^{(3)}$

With the inflation rate and constantly rising costs of labour and services, a local film could never turn a profit under these circumstances even if it plays for several months around the clock before packed houses. The progressively less affordable tickets (in Bulgaria, for example, a film ticket costs twice as much as a ticket for live theatre performance) challenge even this wild assumption. At the same time, the number of imported films, especially American, has jumped between 8 to 10 times (without taking into consideration films on video).

This massive and unchecked influx of American films after 1989, held for so long beyond the ideological pale, has been quoted as one of the major reasons for the current crisis. The simultaneous withdrawal of state subsidies and lack of private investment, are cited as another. There is however a third reason for this crisis, dating back to the times of Communist censorship. Eastern European filmmakers, being preoccupied with the game of hide-and-seek with the Communist authorities, have forgotten or chosen to ignore the so-called "mass viewer" and the popular film genres. And now they are paying a dear price for this negligence. ${ }^{(4)}$

Paradoxically, the only agency to exercise some kind of organised and well financed protectionism in postCommunist cinemas, is the Brussels-based Eurimages. It is an European Union agency that has helped produce more than 30 films across the region, and that sponsors two to three repertory film theatres in each country, which happen to be the only places where people could still see their national film production.

The principle goal of Panorama was to transcend media stereotypes by assembling an adequate picture of the diverse post-Communist reality, and to offer an overview of the basic trends in the new Central and Eastern European cinema. The selected works reaffirm the traditional social commitment of Central and East European filmmakers in times of swiftly shifting values and mores when the Old is no more, and the New has not emerged yet.

Central and Eastern European cinema as presented by the Panorama selection, has embarked on a double quest: the Quest for the Lost Viewer, and the Quest for the Truth -- in times past and present. In the light of all the difficulties mentioned above the drive of Central and East European filmmakers to stand up to the challenges of the global film market without sacrificing the national specificity of their films is a commendable effort reminiscent more of martyrdom than of the simple exercise of a favourite métier.

The Quest for the Lost Viewer flaunts two main genres: the Mafiosi thriller and melodrama. (I have excluded from the selection a few occasional literary adaptations, and one or two rags-to-riches comedy on the sudden happiness of restitution with telltale titles like the Polish film It Is Better to Be Beautiful and Rich, or the Slovak It Is Better to Be Rich and Healthy than Poor and Sick).

The Mafiosi thriller puts to a very serious test the adaptability of Eastern European filmmakers to the global market. There are a few Mafiosi thrillers, produced elsewhere (Hungary and Romania, for example), but the genre is most popular in Poland and, also recently, in Russia. The first and extremely successful film in this organic modification of American gangster thriller is the Polish film Pigs (Wladislaw Pasikowski, 1992). It has set the stage for numerous other films in the same vein, featuring similar characters: former members of the secret police turned Mafiosi -- following them through their deadly struggle with other Mafiosi -- Russian, Eastern European or even Italian. The reason for all the violence and blood usually involves some shady trafficking of arms, narcotics, radio active materials etc.

The attempt to emulate the American genre model is overall successful, although it brings to the fore certain artistic inadequacies and moral ambiguities. The traditions of Eastern European cinematographic school go back to the Soviet classical cinema where psychology, slow camera movement and meticulous artificial lighting were of predominant importance. Tight story line, suspense building, quick paced editing, and the ability to reveal a character with a few broad strokes -- the basic prerogatives of the American prototype -- came second, if at all. In the sequel of Pigs, for example, called significantly The Last Blood (1995), the 
attempt to outdo the master in outdoor chase sequences and spilled blood displayed the lack of professional experience with this type of movies. The clumsy pace and pseudo-psychological contemplations mercilessly exposed the loose ends of the plot, the unconvincing characters and above all -- the dubious moral motivation of it all.

It is evident that Central East European directors love this genre, and are on their way of making it the principle vehicle in their Quest for the Viewer. The success of the Mafiosi thriller with the audiences reminds one of the success of the Partisan film genre from the 50s and 60s. Communist cinema adapted the Western genre to create its most popular films about the WWII Resistance movements in Central and Eastern Europe. There is however a major obstacle to the further development of gangster film formula in post-Communist conditions: filmmakers are still ambivalent whether to condemn their heroes as greedy and ruthless villains, killing mainly for hire, or to represent them as knights of sorts. Even though Communism left a legacy of total confusion of values, there are limits that could not be trespassed even by the most ambitious and irresponsible filmmaker. The Quest for the Lost Viewer in Central and Eastern Europe is apparently impossible to separate from the Quest for the Truth. That is why it takes more than skilful professionalism to repeat the success of Pigs, where the delicate balance between appreciation and condemnation was brilliantly observed.

The Quest for the Lost Viewer has been recently replenished with another classic genre, that of melodrama. But while Mafiosi thriller is a cultural import par excellence, melodrama has a long standing tradition in Eastern and Central European literary, theatrical and film experience before WW II. Actually, almost all films preserved from that period are melodramas. Under Communism, traditional melodrama was virtually outlawed -- it was too attractive for the Viewer, and there was too much Truth in it for its own good. It was dangerously concerned with private emotions and social tensions, while the priority of the official art was to encourage public activities and mass beliefs.

The revival of melodrama, however, is hampered by the already mentioned absence of nominal consensus on what the dominant values of the post-Communist society are. That is why numerous melodramas, made otherwise with some skill and good actors, do not go beyond second rate tear-jerkers. The only myth they unsuccessfully try to activate is that of Amor Omnia Vincit. Although their characters prefer death for love to marriage for money, the reality infiltrates the film fabric and shouts "false." No matter what passions fume on screen, they inevitably leave the viewer with the impression of storms in a glass of water.

The legacy of moral relativism, left by the totalitarian agencies through terror, fear, and relentless propaganda manipulation, has proved to be a major problem after the fall of Communism, along with the economic collapse. The melodramas, selected for Panorama -- the Hungarian Sweet Emma, Dear Böbe (Istvan Szabo, 1992), the (East) German It is always Better There, Where We Are Not (Michael Kleier, 1990) and the Czech Indian Summer (Saša Gedeon, 1995), are challenging this legacy of moral relativism. For them the Quest for the Lost Viewer is inseparable from the Quest for the Truth, for the need to resolve the unprecedented crisis of self-knowledge, induced by Communism. Such an approach turned out to be a solid guarantee for their success with festival juries and audiences. Along with the emotional torment of their heroines and heroes, these films manage to throw light on the larger social picture, overtaken by the omnipresent phantom of ambiguity and uncertainty.

There is an increasing number of films that seem to ignore the Quest for the Lost Viewer, and indulge only in a passionate Quest for the Truth. They are overburdened with heavy metaphors, long pauses, or hysterical actions and noises. The impression is that these films release pent up dissident energies from totalitarian times, although the setting is contemporary (or generally in our times). They engage passionately in breaking taboos -- from sexual to political, for now they are knocking on open doors. These films could be studied as psychological evidence of the profound crisis of self-knowledge -- on personal and social level. They represent also a catalogue of inhibited and uninhibited myths and counter-myths of the collective unconscious that keep reproducing themselves and represent a source of permanent frustration.

The list is extremely long, but as none of these films made it to the final selection, it is enough to mention Polish Death, End of the World, Seishels, Conversations with the Man in the Wardrobe from Poland, Silence, Exitus, The Forbidden Fruit and Something in the Air, from Bulgaria, The Oak from Romania, etc. 
The Panorama selection included a number of films that look in a sophisticated and original artistic way for the roots of the current crisis of self-knowledge. Prudent explorers as they are, Central and Eastern European filmmakers take their viewers on a Quest to find the Truth about the recent history of Communist totalitarianism. They penetrate deep into the mechanism of totalitarian conscience, thus exposing the roots of the current post-Communist drama. Films like Temptation (Barbara Sass, 1996) from Poland, Romanian The Earth's Most Beloved Son (Serban Marinescu, 1993), The Outpost (Peter Gothar, 1994) from Hungary, Day of Forgiveness (Radoslav Spassov, 1992) from Bulgaria, The Fortress (Drahomira Vihanova, 1994) and Thanks for Each New Morning (Martin Steindler, 1994) from the Czech Republic, and the German Lost Landscape (Andreas Kleinert, 1992) deal with the legacy of totalitarianism, ridden with guilt and betrayal. Satantango, the latest opus of the hottest Hungarian director Bela Tarr is a seven-hour cinematic experience that takes the viewer on a unique trip into the macabre world of total manipulation, where people have no choice but to become willing participants in their own destruction.

Experiment has never been the strong point of Central and Eastern European cinema. Suppressed before because of ideological restrictions, and today due to lack of commercial interest, experiment nevertheless finds its way mainly -- and paradoxically -- as financially the more viable solution. Meat (1992), Conspirators of Pleasure (1996) and From Scratch (1996) prove that the simplest and cheapest solutions could constitute a valuable artistic experiment, provided the director has the Midas touch of a Piotr Shulkin, a Jan Svankmajer or an Ivan Pavlov.

The Quest for the Lost Viewer and the Quest for the Truth about the present state of affairs in Central and Eastern Europe have merged in highly artistic and viewer-friendly way in Bolshe Vita (Ibolya Fekete, 1995) from Hungary, Jancso-The Water Magician (Jan Jacub Kolski, 1993) and Crows (Dorota Kedzierzawska, 1994) from Poland, in The Ride (Jan Sverak, 1994, Czech Republic), The Garden (Martin Sulik, 1995) and Paper Heads (Dusan Hanak, 1995) from Slovakia, in The Snails' Senator (Mircea Daneliuc, 1996) from Romania and When I Close My Eyes (Franzi Slak, 1993) from Slovenia, in Neon Tales (Eldora Traykova, 1992) from Bulgaria. Without fear and hate, these films are the ultimate artistic exposure of the trappings of the New Alienation, the tensions between the New Rich and the New Poor, the dawning of the New Chaos, the bitterness and the frustrations, summed up splendidly in the subtitle of the Hungarian burlesque Junk Movie -- We won, so what?

The Panorama presented a collection of films that are reaching out for the Lost Viewer and the Truth; and films that are taking the Lost Viewer on a Quest into the depths of her/his own soul, suggesting that the crisis of self-knowledge could be resolved if people are brave enough to find out the Truth not only about their past and present, but also about themselves.

The goal of Panorama was to catch post-Communist cinema in a moment of transformation, in a flux and to suggest -- once again -- that all rumours about the death of Central and Eastern European cinema have been largely exaggerated.

\section{Notes}

1. Bulgaria, Czech Republic, Germany, Hungary, Poland, Romania, Slovakia, Slovenia.

2. Twenty-five, twenty-two, and twenty feature films respectively for 1996.

3. This data is taken from official bulletins of Eureka Audiovisuelle, a European Union cultural agency, based in Brussels.

4. This author has thoroughly discussed this subject in the article "Les cinemas de l'Europe de l'Est et les genres populaires", published in Ciné-bulles 14, 1, 1995.

\section{Author Information}

Christina STOJANOVA teaches at the Department of Media Production and Studies at the University of Regina, Canada. She has contributed to Cine-bulles, KinoKultura, and the Montreal Gazette. Her publi- 
cations include chapters in Berlin Culturescapes, Making it Like a Man: Canadian Masculinities, Eastern European Cinema, Traditions in World Cinema, Horror International, Alternative Europe and Cinema and Globalization. 